\title{
Economic Policy Shifts in Sri Lanka: The Post-Conflict Development Challenge*
}

\section{Prema-chandra \\ Athukorala \\ Arndt-Corden Department of \\ Economics \\ College of Asia and the Pacific \\ Australian National University \\ Canberra, Australia \\ Prema-chandra.athukorala@anu .edu.au}

\section{Sisira Jayasuriya}

Department of Economics

Monash University

Melbourne, Australia

Sisira.Jayasuriya@monash.edu

\begin{abstract}
The end of the long civil war in Sri Lanka in 2009 generated widespread expectations of a peace dividend that would enable the country to embark on a period of sustained economic growth. Recent developments have dampened that optimism, however, rekindling fears that Sri Lanka's tale of missed opportunities may continue. After showing remarkable resilience during decades of war and conflict, the Sri Lankan economy has failed to capitalize on the window of opportunity presented by the end of the military conflict. In the aftermath of military victory, there has been a sharp reversal of trade liberalization and a marked shift back towards nationalist-populist state-centered economic policies, reflecting the pressures of resurgent nationalism, an unprecedented concentration of political power in a small ruling group, and the influence of some powerful vested interests. Unfortunately, a return to the failed past policies of inward-oriented development strategies offers no viable solutions for the problems confronting small, capital- and resource-poor countries in today's globalized world. Sri Lanka must change both its political practices and economic policies drastically and urgently to cope with the huge development challenges facing it in an environment of global economic turbulence.
\end{abstract}

\section{Introduction}

Sri Lanka had been trapped for a quarter of a century in a long, bloody, and seemingly intractable separatist war until 2009 when the government crushed the separatist forces and achieved a decisive military victory. This victory was

\footnotetext{
* Without implication, we thank Dushni Weerakoon for sharing her insights, data and unpublished material, and participants at the meeting of the Asian Economic Panel, Keio University, Tokyo on 16-17 September 2011 for their comments and suggestions.
} 
widely welcomed by the majority of the Sri Lankan population and the international community despite unease about the conduct of the military during the conflict. The end of the war generated a surge of optimism about the economic prospects for Sri Lanka, with widespread expectations of a peace dividend that would enable Sri Lanka to embark on a period of sustained economic growth.

The immediate post-conflict developments appeared to validate that optimism. The government was well entrenched with a commanding majority within the legislature and strong popular support (at least among the majority community). It faced a deeply divided and politically weakened opposition. Initially the international community was reluctant to subject the Sri Lankan government to any serious political pressure over its handling of the war and reported atrocities, and aid and assistance flowed in from traditional Western donors and international agencies as well as from China and India. The tourist industry, which had been heavily affected by the war, recovered strongly. Internal political stability and the international acceptance of its legitimacy enabled the Sri Lankan government to raise additional funds through commercial borrowings and undertake large public expenditure programs. It appeared as if the window of opportunity presented by the end of conflict had been grasped by the government to steer the country toward political reconciliation and economic growth.

With renewed investor confidence in the country, Sri Lanka experienced a substantial economic recovery. GDP growth in 2010 reached 8 percent, up from 3.5 percent in 2009, inflation came down from 22.6 percent in 2008 to 6 percent in 2010, unemployment fell from 5.7 percent in 2009 to 4.9 percent in 2010, the fiscal deficit narrowed, foreign reserves went up, and the Colombo stock market, having nearly doubled in value in 2010, was the second best performer among global markets for two years running. However, as the large and rapidly growing literature on postconflict recovery has shown, although a resurgence of growth in the immediate aftermath of an end to a violent conflict is often observed, there is no guarantee that such a recovery will be maintained over the medium to long term. ${ }^{1}$ In Sri Lanka's case, it did not take long for the early optimism to fade. By 2011 developments in economic policy as well as in the political arena started to raise concerns about the sustainability of the recovery. In early 2012, in the context of slowing economic growth, a sharp deterioration of the current account and rapidly declining foreign reserves, the authorities were compelled to undertake a substantial devaluation of the currency and unpopular measures to curb public expenditures, and to increase their reliance on short-term commercial borrowings in international capital markets.

1 For reviews of literature, see the recent World Development Report 2011 devoted to "Conflict, Security and Development" and Coyne and Mathers (2011). 
In this paper we examine the Sri Lankan experience, recognizing that a range of factors including the specific historical background and the nature of social and political institutions interact in complex ways to determine the post-conflict economic performance and political evolution. In particular, we consider how the nature of the political coalition that enabled the military victory has, in turn, had a major influence on the post-conflict economic policies in ways that may undermine the country's long-term growth prospects.

The paper is structured as follows. In Section 2, we provide a brief historical background to the conflict and its economic consequences, as well as the political economy context that shapes policy making in the post-conflict period. Section 3 discusses recent macroeconomic developments with particular attention on the role of public sector investment, fiscal deficit and external financing issues, and their impact on investment and export performance. In Section 4 we discuss the relationships between these issues and the political economy, and assess the likely evolution of policy and medium-term prospects for the economy.

\section{Background to the ethnic conflict and separatist war}

The Sri Lankan separatist war that plunged the country into 25 years of violence and destructive conflict has complex historical, political, and economic roots. It is necessary to have some understanding of this background to understand the nature of current developments and to assess the likely future trajectory of Sri Lanka's political and economic evolution. ${ }^{2}$

Sri Lanka is a small, multi-ethnic and multi-religious island nation located at the southern tip of India, with per capita income (in 2009) of US\$1,990 (or in purchasing power parity [PPP] terms, $\$ 4,720) .{ }^{3}$ Despite its low income level, from the 1950s Sri Lanka enjoyed a reputation for having social or other human welfare indicators such as literacy and life expectancy comparable to economies with much higher incomes. In 2008, life expectancy was 70 for men and 78 for women, and adult literacy was over 90 percent. It remains the most affluent country in South Asia in terms of both income and broader welfare indicators, with a human development index value of 0.658 , ranked 91 overall but well above its South Asian neighbors, so that it

2 We do not discuss in detail the roots of the separatist struggle. A more detailed discussion of the post-independence economic and policy history up to the early 1990s, including the economic background to the social and ethnic conflicts that erupted in the 1970s and 1980s, is in Athukorala and Jayasuriya (1994). For discussions that focus on the socio-ethnic conflicts in Sri Lanka, see Abeyratne (2004), Dunham and Jayasuriya (2000), Richardson (2005), and Wilson (1988).

3 Figures sourced from World Bank (2011). 
Table 1. Sri Lanka and selected Asian countries: Purchasing power parity GNP relative to the United States, 1950, 1960, and 1970

\begin{tabular}{lccr}
\hline & $\mathbf{1 9 5 0}$ & $\mathbf{1 9 6 0}$ & $\mathbf{1 9 7 0}$ \\
\hline Sri Lanka & 11.4 & 12.5 & 9.3 \\
India & 7.1 & 7.4 & 6.0 \\
Pakistan & 9.0 & 6.8 & 8.1 \\
Indonesia & - & 5.8 & 4.8 \\
Malaysia & 14.6 & 15.1 & 15.6 \\
Philippines & 10.3 & 11.5 & 10.8 \\
Singapore & - & 16.6 & 24.2 \\
South Korea & 7.6 & 8.7 & 12.8 \\
Thailand & 9.6 & 9.6 & 11.9 \\
\hline
\end{tabular}

Source: Kravis, Heston, and Summers (1983).

Note: - Data not available.

has often been described as the "best in South Asia" (Wriggins 1960). This masks the steady deterioration of its relative position in Asia over time, however.

Sri Lanka ranked as one of the most prosperous and developed Asian countries in the immediate post-independence years and well into the 1950s, with per capita income (and other development indicators) placing it not only well above its South Asian neighbors but also ahead of countries such as (South) Korea and Thailand (Table 1). It had a vibrant democracy, an open economy with strong commodity exports (tea, rubber, and coconut products), a high level of education, an absence of extreme poverty and inequality, good physical infrastructure and governance structures, and was "an oasis of stability, peace and order" (de Silva 1982) in a region of violent turmoil and conflict. Sri Lanka also had strong publicly funded social welfare programs that had been initiated during colonial rule and then extended during the late 1940s and early 1950s by the post-colonial governments. These provided literacy, basic health care, and key staple foods to the population, enabling the country to maintain and build on the already relatively healthy social indicators it inherited from the colonial era.

But the early promise of strong economic growth was not sustained. From the mid 1950s prices of its key export commodities began to experience a long secular decline. Although periodically interrupted by "tea booms," Sri Lanka entered an era of balance of payments crisis, import restrictions, and slow growth. Import restrictions, initially imposed to address payment difficulties, became increasingly restrictive as the development strategy shifted to import substitution industrialization (ISI) policies and pervasive state interventions in the economy under the influence of socalled "socialist" populist-nationalist ideology. ${ }^{4}$ The nationalist-populist Sri Lanka Freedom Party (SLFP) alternated in government with the right-of-center United

4 Sri Lanka's strong left-wing socialist political parties were initially opposed to import 
Figure 1. Sri Lanka's per capita GNP relative to Singapore, South Korea, and Malaysia (percent)

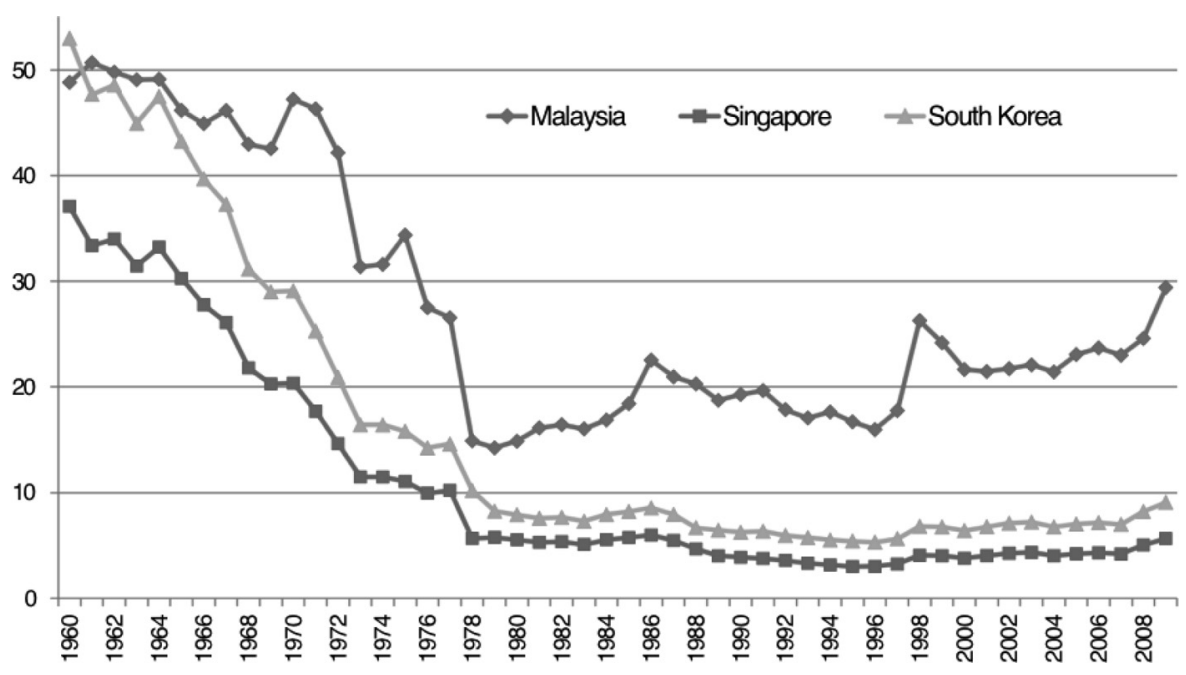

Source: Based on data compiled from World Bank, World Development Indicators database.

National Party (UNP) that espoused more liberal pro-market policies. By the mid 1970s Sri Lanka had become one of the most inward-oriented economies of the world, with an economy dominated by extensive state ownership and control of major industries and extremely stringent and restrictive trade, exchange, and price controls and rationing.

Growth slowed down and virtually ceased during the early 1970s under the stresses of the first oil and commodity price shocks. Sri Lanka rapidly fell behind the fast growing East Asian economies (Figure 1).

The reasons for Sri Lanka's growth slowdown have been the subject of much debate. Many analysts, particularly those associated with international donor agencies such as the World Bank, argued during the 1960s and particularly during the 1970s that government expenditures on health, nutrition, and education (often described as "consumer subsidies"), which delivered high levels of social indicators, were primarily responsible for the slowdown by diverting government resources away from direct growth-oriented investments. Others have pointed to the role such social

restrictions on consumer goods. During the 1960s, however, they shifted their position and became ardent supporters of ISI policies (Athukorala and Jayasuriya 1994). 
expenditures played in maintaining political stability at low cost—Sri Lanka's expenditure on police and military forces was among the lowest in the world, arguing that the primary cause of the slide to slow growth and stagnation was the turn away from international trade that underpinned ISI policies, aggravated by an environment that was hostile to long-term private investment. ${ }^{5}$

The emergence and subsequent dominance of nationalist ideology in Sri Lankan politics also undermined the ethnic harmony that had made Sri Lanka the exception in South Asia when violent bloodletting accompanied independence in British-ruled India. Until the time of independence all major political parties were multi-ethnic in composition and mainstream politics was dominated by class-, rather than ethnicor religious-based political differences. But by the mid 1960s all major political parties had acquired a distinct ethnic coloration as even the two main left-wing parties, which had been staunch defenders of ethnic equality, gradually embraced policies that catered to the extreme nationalistic views of the majority Sinhalese community.

A combination of slow economic growth, rapid population growth, and the state domination of the economy led to the minority Tamil community (about 20 percent of the total population) being subjected to discrimination as employment avenues were increasingly subject to patronage politics and access to political power. In the Sri Lankan system of parliamentary democracy, the preferences of the majority Sinhala community, which constitutes around 70 percent of the population, determined who won government and controlled the state. ${ }^{6}$

The state bias in economic policies meant that the slow-growing pool of employment was concentrated in the state sector. The government, as was the case in many developing countries pursuing similar policies, had become the "employer of last resort" and the public sector outpaced the private sector in employment creation, at least in the "formal" sector. The public sector share of GDP had increased to around 15 percent by the mid-1970s from less than 6 percent in 1961 and it accounted for over 50 percent of employment and 60 percent of value added in the "organized" manufacturing sector by the late 1970s. ${ }^{7}$ This had a particularly severe effect on the employment opportunities of Tamil youth because, as in many other countries in

5 For a useful review of this debate, see Osmani (1994).

6 One of the first acts of the post-colonial government was to abolish citizenship rights and disenfranchise around one million people. This was opposed by left-wing parties at the time but they, too, came to accept this over time.

7 See Athukorala and Rajapatirana (2000). 
similar circumstances, political patronage had become a major factor in public sector employment. ${ }^{8}$ Tamil youth were further disadvantaged in gaining public sector employment by the imposition of proficiency requirements in Sinhalese for public sector employment and the de facto race-based quotas for entry into higher education institutions. This deepened Tamil dissatisfaction with the Sinhalese-dominated government and political parties, and provided the breeding ground for separatist ideologies among the Tamil youth, which spawned several radical movements among which the Liberation Tigers of Tamil Eelam (LTTE) subsequently established its dominance.

Dissatisfaction with the economic consequences of ISI policies and slow growth were not confined to the Tamil youth. In the late 1960s large numbers of Sinhalese youth embraced a new radical political movement, the Janatha Vimukthi Peramuna (JVP - the People's Liberation Front), which was influenced by Maoism and theories of rural insurrection but also embraced Sinhalese Buddhist nationalism. This movement organized an armed uprising in 1971 that was brutally crushed by the government. It was not accidental that the leadership of both the Tamil and Sinhalese radical nationalist movements were drawn from the most economically disadvantaged rural peasantry and fishery communities, in the North in the case of the Tamils and in the South in the case of the JVP; ${ }^{9}$ it reflected the fact that their political radicalization had common economic roots.

The impact of the global recession of the early 1970s and government policy responses led to food shortages, rationing, and cuts to consumer subsidies, which made the center-left SLFP- led government extremely unpopular. A massive electoral backlash in 1977 saw a new UNP government, pledged to "open economic policies," swept into power.

The government launched a series of fundamental liberalization policy reforms in 1977 and 1978 that marked a decisive break with decades of ISI policies. ${ }^{10}$ With these reforms Sri Lanka pioneered policy liberalization in South Asia, a decade or more ahead of its neighbors. The results of policy liberalization, enhanced by a

8 See World Bank (1979) for a discussion of the role of political patronage in public sector employment.

9 Hettige (2004), Richardson (2005), Moore (1993), and Obeyesekere (1974).

10 For details on the reform process, see Rajapatirana (1989), Athukorala and Jayasuriya (1994), Moore (1997), Dunham and Kelegama (1997), Snodgrass (1998), and Athukorala and Rajapatirana (2000). For a review of the Sri Lankan experience with trade policy reforms from a comparative South Asian perspective, see Panagariya (2002). 
massive flow of aid and assistance from international donor agencies and countries into large infrastructure projects and the establishment of "free trade zones," were dramatic.

Growth surged, from an average of 2.9 percent during 1970-77 to over 6 percent during 1978-83. Sri Lanka attracted foreign investors into the labor-intensive garments sector and this led to the establishment of a dynamic labor-intensive export industry linked to international supply networks. The tourism sector also started to boom, and Sri Lanka appeared set to establish itself as a prime tourist destination. Sri Lanka enjoyed the advantages of an early entrant into these industries where it had strong natural comparative advantage. This was a golden window of opportunity for Sri Lanka. China was yet to start its liberalization; other countries such as India and Vietnam were more than a decade away from such reforms. The country seemed poised to embark on a trajectory of rapid growth that would enable it to emulate the dynamic East Asian economies.

But this was not to be. The new government not only failed to maintain the initial pace of liberalization but also diverted resources to a huge foreign aid-supported public investment program of low economic returns and to employment expansion in public enterprises. Government spending rose sharply; food subsidies were drastically cut but increases in transfers to loss-making state enterprises offset these budget savings. ${ }^{11}$ Although some of the investment projects in irrigation, land development, and hydropower had some economic rationale, other components of this public sector investment program, such as the construction of a new capital and a large-scale house-building program, had questionable economic value. To the extent that this public sector spending boom generated inflationary pressures and Dutch disease effects, it undermined the impact of trade liberalization by weakening the incentives for growth of labor-intensive export industries.

The economic policy changes were accompanied by a series of political measures that were later to have a profound impact on the social and political environment of the country. From the outset the new government exhibited authoritarian tendencies in the political arena. The constitution was changed, and the Westminster system of parliamentary democracy was replaced with a system that centralized executive power in the hands of the President. The government intimidated both Sinhala and Tamil opposition groups, at times using physical force, disenfranchised the ex-Prime

11 Real government spending on food subsidies were slashed by nearly 70 percent during 1979-82, and annual transfers to loss-making state owned enterprises expanded; the transfer to the national airline, for example, at times exceeded the total food subsidy during the 1980s. 
Minister, and effectively forced out the leading opposition group in parliament, a Tamil ethnic-based party led by moderate leaders committed to nonviolent political activity. Trade unions, which had been traditionally aligned with the left parties, were dealt a severe blow in 1980 when tens of thousands of public sector workers were dismissed for going on strike.

In this context, ethnic tensions heightened in the country. The implementation of the trade liberalization policies and the composition and regional investment focus of the public investment programs were perceived as discriminatory by important sections of the Tamil minority. This was particularly the case in relation to agricultural trade liberalization and land development programs. ${ }^{12}$ The virtual expulsion of the oppositional Tamil members of parliament, the collapse of the political influence of the left-wing parties that had abandoned their previous opposition to Sinhala chauvinism after forming a coalition with the SLFP, and heavy-handed tactics used against Tamils protestors aggravated the alienation of the Tamil community from the Sinhala-dominated political mainstream. These led to a sharp radicalization among Tamil youth and many rejected the moderate leaders of the Tamil ethnic political parties and embraced new, radical movements committed to a separate state through armed struggle.

An attack on security forces by an armed group of the LTTE in July 1983 led to a violent anti-Tamil program and mob attacks in southern parts of the country (the "Black July"), including the capital, Colombo, producing hundreds of thousands of Tamil refugees. There were widespread allegations of complicity of sections of the armed forces and government supporters in these attacks. In any case, the manner in which the riots were handled by the government deepened Tamil resentment against the Sinhala-dominated government and sympathy and support for separatism. This was the start of the secessionist war led by the LTTE which, until crushed by government forces in 2009, established a de facto separate state in parts of the North and East of the country, and dominated political, social, and economic life for the next 25 years.

The Sri Lankan experience offers some lessons of broad relevance to the debates about economic development and ethnic diversity. ${ }^{13}$ The ethnic conflict with its attendant economic costs in Sri Lanka was rooted not simply in the existence of ethnic diversity in the country but was also the result of the adoption of ISI policies by significant sections of the political elite. If a development strategy had been adopted

12 See Bandara and Jayasuriya (2009) and Dunham and Jayasuriya (2000).

13 See for examples Collier and Hoeffler (2004), Collier (1999), and Easterly and Levine (1997). 
that permitted greater scope for employment creation outside the state sector, as was the case in Malaysia, the evolution of the economic and political history of Sri Lanka may have been substantially different. ${ }^{14}$ It is not irrelevant to this issue that until the dominance of ISI strategy in economic policies, the Sri Lankan political scene was marked by sharp class, rather than ethnic, conflicts and polarization.

It must be noted that the social and political tensions of the 1980s were not confined to the Tamil community. With the eruption of the civil war and phasing out of the public sector investment program the economy lost momentum and growth slumped. By the late 1980s, discontent and radicalization among Sinhala youth was widespread and led to a second JVP-led armed uprising, this time on a much larger scale than in 1971, which virtually paralyzed the Sinhalese-dominated Southern parts of the country. By the time it was crushed in 1989, at a high cost in human and economic terms, Sri Lanka had moved toward a major economic crisis that necessitated recourse to the IMF and the implementation of a series of radical reform measures.

\section{Economy and society: From the second wave of reforms to the end of the war}

This second wave of reforms marked an important watershed in the economic policy arena. It involved an ambitious privatization program, further tariff cuts, and simplification of the tariff structure, removing exchange controls on current account transactions and several important liberalization measures in foreign investment regulations, which strengthened the outward orientation of the economy. This package of reforms not only strengthened incentives for the expansion of labor-intensive export industries and re-infused dynamism into the economy, it also established a policy orientation that replaced the traditional left-right ideological divide and established a de facto consensus across the political spectrum on the basis of a promarket, open, liberal economic policy regime (Dunham and Kelegama 1997).

After 17 years in government, the UNP lost power at the 1994 general elections to the Peoples' Alliance, a center-left coalition led by the SLFP, which had governed the country during most of the era of economic dirigisme. There was no significant change in the broad direction of economic policies, however; the gains from exportoriented industrialization had been impressive enough to set the stage for "leading the left to the right" (Moore 1997, 1009). Indeed, the new government extended the privatization and deregulatory policies and pursued trade and macroeconomic policies that were largely indistinguishable from the previous government. All in all, by

14 See Bruton (1992) for a comparative study of Malaysia and Sri Lanka. 
the mid 1990s Sri Lanka appeared to be "at the point of moving into an important policy phase marked by shifting the agenda away from protection and toward achieving a stable and predictable economic policy environment" (Cuthbertson 1997, 47).

Over the next two decades the country experienced severe internal political instability, the conflict with the LTTE dragged on at a huge cost to the economy, ${ }^{15}$ and the economy was buffeted by several serious external shocks including the 1997-98 Asian financial crisis, the 2004 Asian tsunami, the surge of world oil and food prices during 2007-08, and the 2008-09 global financial crisis that followed. Nevertheless, the Sri Lankan economy demonstrated a remarkable degree of resilience, with GDP growth averaging 5.3 percent in the 1990s and 5.5 percent per annum during 2000-09. ${ }^{16}$ The human development index improved from 0.558 in 1990 to 0.658 in 2010 and the headcount index of poverty came down from 22.7 percent in 2002 to 7.7 percent in 2009-10. The economy benefitted from a strong boom in tea prices in the mid 1990s, but even allowing for that, Sri Lanka's growth performance during this period appears nothing short of remarkable under the circumstances.

Arguably, these reforms and the basic continuity of the policy thrust through several changes in government were instrumental in enabling the economy to turn in this robust performance. This is not to imply that government policymaking during this period was in any way ideal. The political conditions strengthened the role and power of the state in economic life as military expenditures and the absence of transparency in many transactions opened avenues for large-scale rent extraction. Thus many privatization measures were carried out in ways that enabled favored businesses and government officials to engage in corrupt practices, resulting in a public backlash against privatization that continues to influence policy and perceptions to this day. Corruption was particularly, but not solely, associated with the privatization process, and administrative and managerial inefficiency were pervasive. Large and increasing defense expenditures and political constraints on reducing government spending produced chronic fiscal deficits and inflationary pressures throughout this period. Governments and monetary authorities resisted currency depreciation despite serious overvaluation until compelled to implement adjustment measures when an impending payments crisis left them no choice. ${ }^{17}$ The trade liberalization process suffered a setback because of the pressure for raising

15 Arunatilake, Jayasuriya, and Kelegama (2001) estimated that the cost of the war from 1983 to 1996 was, at a minimum, equivalent to twice Sri Lanka's GDP. The cost during the post1996 period, when the conflict escalated, is likely to have been much higher.

16 Data given in the paper, unless otherwise stated, are from Central Bank of Sri Lanka, Annual Report (various issues).

17 These policies precipitated capital flight and a currency crisis in 2000, and forced a steep devaluation in January 2001, followed by an IMF package; GDP growth was negative in 2001. 
additional revenue from import tariffs to finance the ballooning war budget. The planned reduction of tariffs into a single band had been abandoned by the late 1990s and from then on tariffs were changed frequently in an ad hoc manner. But, despite all this, when the period as a whole is considered (taking into account the fact that this was a period of conflict and war and of severe stress and uncertainty), this record of economic growth was quite impressive.

Despite the unsettled conditions, the reforms dramatically transformed the economic landscape of Sri Lanka (Snodgrass 1998; Athukorala and Rajapatirana 2000; World Bank 2004). The share of manufacturing in GDP rose from around 10 percent in the mid 1970s to over 20 percent (about two percentage points higher than the share of agriculture) by the dawn of the new millennium. The export structure of the economy underwent a remarkable transformation from land-intensive, plantation exports to labor-intensive manufacturing. The share of manufacturing in total merchandise trade increased from 5 percent in the mid 1970s to over 70 percent in the same period, ending the historic dependence on three primary commodities (tea, rubber and coconut products). This successful diversification of the export structure effectively ended the prolonged (1955-75) deterioration of the terms of trade (Athukorala 2004). The export-oriented manufacturing sector emerged as the major generator of employment opportunities in the economy, accounting for over half of total employment growth during the 1980s and 1990s. With the gradual erosion of the dominant role of state-owned enterprises (SOEs), the private sector was largely responsible for the country's economic dynamism. In a summary of the Sri Lankan experience under market-oriented policy reforms, World Bank's Sri Lanka Development Policy Review of 2004 noted that "It would be hard to find a more convincing case of trade and industrial transformation of a small island economy through market-friendly policy reforms" (World Bank 2004). Hence it is understandable that the end of conflict would generate much optimism about the future trajectory of the economy, both inside and outside the country.

Against this backdrop, in the next section we will look at the post-conflict situation, including the political context, to identify the policy challenges and assess the prospects.

\section{Revival of economic nationalism}

President Mahinda Rajapakse, who had won a tightly contested election in 2005, prepared the ground for the government's victory in 2009 with a series of policy ini-

The resulting electoral backlash led to the defeat of the government in parliamentary elections in December 2001. 
tiatives. The new government sharply increased the military budget, rejected political compromises, escalated the military campaign and, supported and assisted by the Western powers, neighboring India and Pakistan, as well as-importantlyChina, decisively crushed the LTTE in 2009. President Rajapakse was acclaimed as a national hero, at least by the Sinhalese majority, as the leader who liberated the country from the scourge of LTTE terrorism; he promised the electorate that he would deliver peace and economic prosperity, the fruits of victory, to the people who had suffered and sacrificed. On the back of the military victory, President Rajapakse consolidated his power by calling fresh parliamentary and presidential elections in 2010, decisively defeating the opposition (and incarcerating the military commander who after leading the campaign against the LTTE had turned against him and challenged him for the presidency). Immediately after the elections, the constitution was amended removing the two-term limit on the tenure of the president (Uyangoada 2010).

In the aftermath of the military victory, the political message that came through the various pronouncements and proclamations of the government and the leaders was the strong assertion of Sinhala Buddhist hegemony in the socio-political life of Sri Lanka. This was also mirrored in the economic policy statements of the government with a strident economic nationalist rhetoric that harked back to the populist programs of the 1960s and 1970s (Government of Sri Lanka 2010; 2011), though prospects of an impending payments crisis had compelled the government to enter into a Stand-By Arrangement (SBA) with the IMF in February 2009, only a few months prior to the military victory (IMF 2012).

This post-victory shift in economic policy rhetoric was not quite a surprise. The medium-term development strategy presented at the elections in 2005 in the Mahinda Chinthana: Ediri Dakma [Mahinda Vision: A Vision for the Future] had already signaled a more populist tone (Government of Sri Lanka 2006). It had proclaimed the need to achieve "balanced growth," through rapid infrastructure development of rural and conflict-affected parts of the country and through the promotion of small and medium enterprises, while conspicuously avoiding any references to further liberal policy reforms. The role of the state was emphasized while privatization of key state enterprises (banking, power, energy, transport, and ports) was explicitly ruled out. It was an eclectic program that was designed to appeal to the government's core rural constituency, as well as the military and small business, while attempting not to alienate big business and international investors, and international donors. The populist policies received strong backing from an anti-liberalization lobby with strong vested interests, and ideological support from a group of senior academic economists who used the failure of reform policies to meet initial expectations to argue that the failure of so-called 
"neo-liberal" policies demonstrated the need for returning to a more nationalist economic program. ${ }^{18}$

As shown by the behavior of the People's Alliance (of which Mahinda Rajapakse had himself been a key leader) in 1994, however, a populist election manifesto did not necessarily mean that the policy shifts signalled in it would be actually implemented after an election victory. In fact in 1994 the People's Alliance had gone to the elections with an even more strongly populist manifesto, only to continue-albeit with some minor changes in emphasis—the previous government's pro-market liberal policy program once in government. When Rajapakse became Prime Minister in 2004 (subsequently becoming President in 2005), it was not immediately apparent that he would undertake a significant shift in overall economic policies. Though the appointment of a close political confidante who had no banking experience or economics background to the position of Governor of the Central Bank was a clear sign that economic policy at every level would be subject to the political goals of the government, policy changes appeared to be motivated by the aim of mobilizing resources for an all-out military offensive to crush the LTTE, rather than by a significant change in economic policy direction. It was only after the military victory in 2009 that the Rajapakse government made its policy shift open and explicit. Clearly, it felt politically strong enough to disregard both the domestic critics of its economic policy direction and the directives of international agencies.

Purcell and Ahsan (2011) have documented how Sri Lanka systematically erected new trade barriers through the introduction of various new import taxes, while keeping the standard Customs Duties (which come under the surveillance of the World Trade Organization) virtually unchanged. ${ }^{19}$ By 2009 the Sri Lankan tariff schedule included nine import taxes in addition to the standard customs duty. Of these nine taxes, five were "Para-tariffs": taxes applied only to imports with no domestic equivalent, and hence added to whatever protection was provided to domestic production by customs duties. These were the ports and airport development levy (5 percent of the cost, insurance, and freight [CIF] value of imports), the customs (import duty) surcharge (charged as 15 percent of import duty), the Export Development Board levy (ranging from 10 percent to 35 percent; levied on the CIF value plus a 10 percent imputed profit margin), and the regional infrastructure development levy (applied on automobile imports as 5 percent, 7.5 percent, or 10 per-

18 In assessing the actual outcome, they downplayed (or overlooked) the incomplete and staggered nature of the reform process in assessing actual outcomes (Rajapatirana 2004), while ignoring Sri Lanka's own past experience of failure with inward-oriented policies.

19 See also Pursell (2001a; 2011b). 
Table 2. Sri Lanka: Unweighted average protection rates, 2002, 2004, 2009, and 2011

\begin{tabular}{|c|c|c|c|}
\hline & Customs duties & Para-tariffs & Total protection rate ${ }^{a}$ \\
\hline $\begin{array}{l}\text { November } 2002 \\
\text { Agriculture (HS 01-24) } \\
\text { Industry (HS 25-87) } \\
\text { All tariff lines }\end{array}$ & $\begin{array}{r}21.1 \\
7.6 \\
9.6\end{array}$ & $\begin{array}{l}5.2 \\
2.5 \\
2.9\end{array}$ & $\begin{array}{l}26.3 \\
10.1 \\
12.5\end{array}$ \\
\hline $\begin{array}{l}\text { January } 2004 \\
\text { Agriculture (HS 01-24) } \\
\text { Industry (HS 25-87) } \\
\text { All tariff lines }\end{array}$ & $\begin{array}{r}24.6 \\
8.8 \\
11.3\end{array}$ & $\begin{array}{l}3.5 \\
1.9 \\
2.1\end{array}$ & $\begin{array}{l}28.1 \\
10.7 \\
13.4\end{array}$ \\
\hline $\begin{array}{l}\text { December } 2009 \\
\text { Agriculture (HS 01-24) } \\
\text { Industry (HS 25-87) } \\
\text { All tariff lines }\end{array}$ & $\begin{array}{l}24.6 \\
10.3 \\
12.4\end{array}$ & $\begin{array}{l}25.0 \\
13.7 \\
15.5\end{array}$ & $\begin{array}{l}49.6 \\
24.0 \\
27.9\end{array}$ \\
\hline $\begin{array}{l}\text { January } 2011 \\
\text { Agriculture (HS 01-24) } \\
\text { Industry (HS 25-87) } \\
\text { All tariff lines }\end{array}$ & $\begin{array}{r}25.4 \\
9.1 \\
11.5\end{array}$ & $\begin{array}{l}21.4 \\
10.6 \\
12.2\end{array}$ & $\begin{array}{l}46.8 \\
19.7 \\
23.7\end{array}$ \\
\hline
\end{tabular}

Source: Pursell and Ahsan (2011).

Note: a. All protection rates are percentages of CIF import value. $b$. This predominantly reflects manufacturing protection. Mining (less than 3 percent) accounts for a tiny share of industrial output.

cent of Free on Board value, based on engine capacity). The four remaining import taxes were: the value added tax (12-20 percent), the Social Responsibility Levy (1.5 percent of import duty, other import surcharges and excise duties), the national building tax ( 3 percent, payable on a self-assessment basis by importers, manufacturers, and service providers with a quarterly turnover exceeding Rs 650,000), and an excise duty (7 percent until 2007 and 10 percent since October 2007). These did have domestic equivalent or approximately equivalent taxes; hence they were roughly neutral in terms of protection. In addition to these, a special commodity levy was imposed on imports of a small number of "essential" commodities.

The outcome of these various taxes and levies was a major reversal of trade liberalization from 2004 onward; the total (customs duty + para-tariff) protection rates (TPRs), went up slightly between late 2002 and early 2004, but then more than doubled between 2004 and 2009 (see Table 2). The average protection rate for agriculture increased from 28.1 percent to 49.6 percent, for industrial products from 10.7 percent to 24.1 percent, and for all imports lines from 13.4 percent to 27.9 percent. These protection rates are not only high by world standards, but also show clearly that the trend toward lower average tariffs that started in about 1982 and continued until the turn of the 21st century has been reversed. Further, the tariff structure has become extremely complex again with a high degree of dispersion. After allowing for paratariffs there are 75 different total protection rates ranging from zero to more than 90 percent. A large number (42 percent) of industrial tariff lines have low TPRs of below 10 percent, whereas a third (32.2 percent) of tariff lines have TPRs of 35 percent or higher, with many clustering in the range of 35-60 percent. Almost 
Figure 2. Trade orientation of the Sri Lankan economy, 1959-2010 (percent)

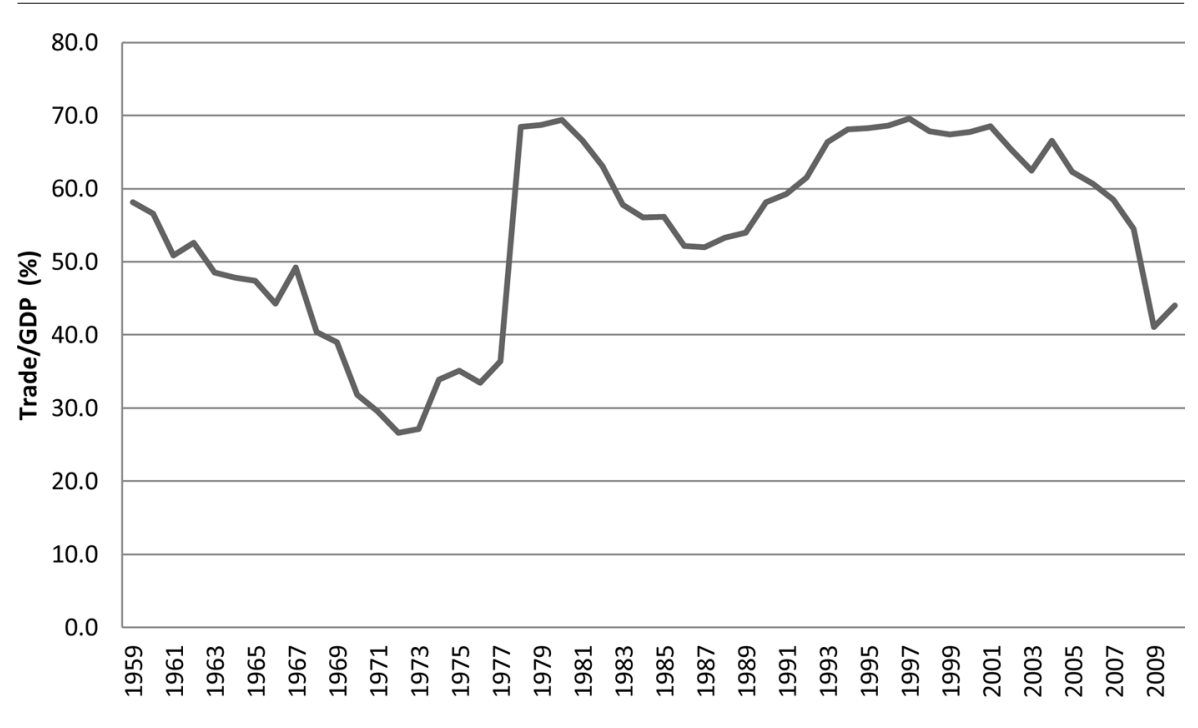

Source: Based on data compiled from Central Bank of Sri Lanka, Annual Report (various years).

40 percent of agricultural TPRs are within the range of 70-80 percent, while only a few (6.7 percent) are below 10 percent.

The TPRs on almost half (46.1 percent) of agricultural tariff lines exceed 50 percent, clearly breaching Sri Lanka's Uruguay Round commitment, which bound nearly all agricultural tariffs at 50 percent. There has been a notable increase in nontariff barriers since 2000, particularly relating to agricultural products. Politically "sensitive products" such as rice and potatoes have been subjected to special import licensing under which the volume of imports permitted is subject to frequent changes. As a consequence, the trade openness of the Sri Lankan economy, measured by the tradeto-GDP ratio, has been falling for several years with a particularly pronounced fall from 2008 onward (Figure 2).

The creeping economic dirigisme is not limited to the import trade regime alone. In 2008 the parliament passed the Strategic Development Projects Act, empowering the minister in charge of the Board of Investment (BOI) to grant exemption to "strategic development projects" from all taxes for a period of up to 25 years. In the Act a strategic development project is defined as be "a project which is in the national interest and which is likely to bring economic and social benefits to the country and which is also likely to change the landscape of the country, primarily through provision of 
goods and services which will be of benefit to the public, substantial inflow of foreign exchange, substantial employment, and technology transfer" (Government of Sri Lanka 2008, 3). This definition leaves a great deal of room for discretion in the investment approval process. ${ }^{20}$

Another measure affecting foreign investments has been the increase in the minimum level of investment required for a company to qualify for a five-year tax holiday under the BOI scheme. Up until 2010 this was US\$ 500,000 but was then increased to US\$ 3 million for projects in all sectors. This minimum threshold seems excessive when compared to that in other countries in the region (Malaysia US\$ 65,000; Thailand US\$ 65,000; South Korea US\$ 50,000; India US\$ 2,100 [World Bank 2010]).

The privatization program was abandoned following the regime shift in 2005. Initially the policy of the new government was not to privatize, but to restructure and improve performance of the existing ventures, with private sector involvement if required while retaining government ownership of at least 51 percent. Following consolidation of power after the war, however, the government has embarked on further expansion of the role of SOEs in the economy by re-nationalizing some previously privatized ventures, revitalizing closed-down SOEs, undertaking new nationalizations, and setting up new state-controlled ventures. An expropriation law, named the Revival of Underperforming Enterprises and Underutilized Assets Act, passed in November 2011 empowered the government to acquire and manage 37 "underperforming" or "underutilized" private enterprises. These enterprises (some of which are said to be profit-making, according to media commentaries) include seven enterprises with foreign capital participation (including Colombo Hilton). The Act thus obviously violates the existing constitutional guarantee against expropriation of foreign-owned assets. Both the Fitch Group and Moody Corporation, two major credit rating agencies, have warned that the bill would erode investor confidence and potentially affect Sri Lanka's investment rating (Goodhand 2012).

Another notable recent development in the Sri Lankan policy scene that marks a clear departure from the industrial policy over the past three decades has been the promotion of a domestic car industry. The present cascading tariff structure in Sri Lanka, characterized by a high import tariff on completely built automobiles (300 percent) coupled with low tariffs on car parts and components (5-10 percent),

20 Projects identified under the Strategic Development Projects Act are largely confined to investments in relation to information technology and business process outsourcing, tourism, and infrastructure (Ekanayake 2011). 
has made local assembly of certain models of automobiles highly privately profitable. ${ }^{21}$ In January 2010 the government introduced an excise duty rebate exception scheme as a further incentive for such companies. Currently an excise duty is charged on all vehicles produced, assembled, or imported into Sri Lanka at 25 percent, 48 percent, and 65 percent, depending on the engine capacity. Under this rebate scheme, automobiles assembled in Sri Lanka are eligible for complete exemption from these duties provided the domestic content is not less than 30 percent of the exactor price and the value of locally manufactured components accounts for at least half of the domestic content. There is also anecdotal evidence that government procurement practices provide further assistance to local automobile assemblers: a company involved in assembly of jeeps has been provided an assured market under a sales agreement signed with the Sri Lankan Army.

\section{Global economic environment and post-conflict developments}

By the time the war ended in 2009 the external environment had changed in an unfavorable manner and the scope for "independent" government action had significantly narrowed. The global economy was reeling from the impact of the 2008-09 global financial crisis and the subsequent recession. Sri Lanka, as a net food and energy importer, had already been badly hit by the global food price surge of 2007-08 and the high oil prices, and growth had slowed in 2008. GDP growth slumped further in 2009, falling below 4 percent even though government spending had surged immediately after the end of the conflict due to election spending and urgent reconstruction expenditures. The already large fiscal deficit ballooned from 7.7 percent of GDP in 2008 to 9.9 percent of GDP in 2009, breaching the agreement reached with the IMF in February 2009 to cut its fiscal deficit to 7 percent of GDP.

Despite this somewhat hesitant start to post-war economic recovery, Sri Lanka appeared set to enjoy its peace dividend by 2010. The external sector (foreign reserves, export earnings) benefitted from improved global economic conditions, domestic agricultural production recovered thanks to better weather, tourism recorded an impressive recovery, remittances from Sri Lankan overseas workers increased, unemployment fell, GDP grew at 8 percent, and inflation remained relatively low. The

21 Since 2006 four assembly plants have been set up under the approval of the Ministry of Industry and Trade. Micro Car Company (2006), Union Enterprise (2008), Universal Auto Assembly (2008), and Frontier Automobile (2010). All these plants are fully locally owned, but operate under licensing arrangements with car makers in China (Union Enterprise and Frontier), Korea (Micro Car), and India (Frontier). All four firms are engaged in simple assembly of imported completely-knocked-down (CKD) units of outdated models that have already been scrapped from their production schedule by the parent companies. 
Table 3. Sri Lanka: Sectoral composition and growth of GDP

\begin{tabular}{lcrr}
\hline & Composition (percent) & \multicolumn{2}{c}{ Growth } \\
\cline { 2 - 3 } & $\mathbf{2 0 1 1}$ & $\mathbf{2 0 1 0}$ & $\mathbf{2 0 1 1}$ \\
\hline Agriculture & 11.2 & 7.0 & 1.5 \\
Tea & 1.0 & 13.8 & -0.9 \\
Paddy & 1.5 & 17.5 & -8.4 \\
Other food crops & 3.6 & 4.4 & 2.5 \\
Industry & 29.3 & 8.4 & 10.3 \\
Manufacturing & 17.3 & 7.3 & 7.9 \\
Construction & 7.1 & 9.3 & 14.2 \\
Services & 59.5 & 8.0 & 8.6 \\
Wholesale and retail trade & 23.6 & 7.5 & 10.3 \\
Transport and communication & 14.3 & 11.9 & 7.3 \\
Banking, insurance and real estate & 8.8 & 7.5 & 7.9 \\
Government services & 7.1 & 5.4 & 1.2 \\
\hline
\end{tabular}

Source: IPS (2012) based on Central Bank of Sri Lanka, Annual Report, various years.

good growth performance continued through 2011, despite a sharp weather-related fall in agricultural output. The Sri Lankan equity market boomed. ${ }^{22}$ The government appeared to have succeeded not only in winning the military battle but also in discovering a strategy for sustained economic growth.

As can be seen in Table 3, the main drivers of this GDP growth were the nontradable industries (construction, transport, utilities, trade, and other services), reflecting the important role of major public sector construction and infrastructure development projects. These sectors accounted for over two-thirds of the total increment in real GDP between 2005 and 2011. Manufacturing grew only at a modest rate, resulting in a decline in its share in GDP from 18.5 percent during 2000-04 to 17 percent by 2011. Within manufacturing, the largest contributor to growth was the food, beverages, and tobacco product sector where the production is predominantly domestic market-oriented; sectors such as textiles and garments, rubber and plastic products, and non-metallic mineral products, where export production is concentrated, recorded much slower growth. ${ }^{23}$

A large-scale reconstruction effort with public sector involvement was clearly necessary after a quarter century of destruction, neglect, and decay of essential physical infrastructure. Although such projects can give rise to some real exchange rate appreciation and Dutch disease pressures, such effects are temporary; construction and rehabilitation of infrastructure strengthens the productive base of the economy

22 Coyne, Dempster, and Issacs (2010) claim that movements in the Sri Lankan stock market index have been a good indicator of the feasibility or prospects of the sustainability of peace.

23 Thus the statement made by an IMF review team in mid-2012 that "the sectoral composition of Sri Lanka's economy has not changed significantly since its last Review" (IMF 2012, 5) is not consistent with the actual data. 
and enables expanded production of both tradables and nontradables, and thereby delivers growth benefits over time. ${ }^{24}$ Many government infrastructure projects, however, such as a modern port and other facilities (being built with Chinese assistance), are located in the Southern regions of Sri Lanka-the heartland of the electoral support base of the Rajapakse family. The prioritization and economic efficiency of these "flagship projects" are questionable, and they share many similarities with some components of the public investment program of the UNP government of 1977.

Even when largely foreign-funded, these projects pull in substantial domestic resources for counterpart funding and contribute to the fiscal deficit. According to the $\operatorname{IMF}(2010,4)$, in 2009, the failure to meet the deficit target was due to government spending on "faster than programmed, lumpy disbursements for a couple of large foreign financed infrastructure projects and for their counterpart funds." 25 They also open up avenues for lucrative contracts and rent extraction by those who control the levers of state power.

Inefficient public investment projects of this type may not become a major impediment to a sustainable growth recovery if they are a minor part of the overall investment program and the government is in a strong fiscal position. But this is not the case in Sri Lanka; chronic fiscal deficits have been a feature of Sri Lanka's macroeconomic policy environment for decades and successive agreements with the IMF that promise deficit reduction have been breached with monotonous regularity. The consequences have been grave. They have constrained the government's ability to finance high priority investments in physical infrastructure, health, and education; crowded-out private investment; generated inflationary pressures and real exchange appreciation; and eroded the competitiveness of tradable sectors, contracting net exports and giving rise to periodic payments crises and boom-bust cycles. ${ }^{26}$

In contrast to the 1977 public sector investment boom that came in the context of a major liberalization program involving a major currency depreciation-which at least partially offset some of the negative real exchange rate appreciation pressures—the Rajapakse government's public investment program was implemented with a strong Central Bank commitment to maintain the "dollar value of the Rupee" by resisting any pressures for nominal depreciation.

24 See Adam and Bevan (2006) for an analytic discussion of these issues related to intertemporal economic impact of public infrastructure projects.

25 http://www.imf.org/external/pubs/ft/scr/2010/cr10333.pdf.

26 For a discussion of some aspects of Sri Lanka's fiscal deficits and public debt issues, see IMF (2009) at: http://www.imf.org/external/pubs/ft/dsa/pdf/dsacr09310.pdf. 
Figure 3. Sri Lanka: Real exchange rate and its components, 2004:Q1-2012:Q2

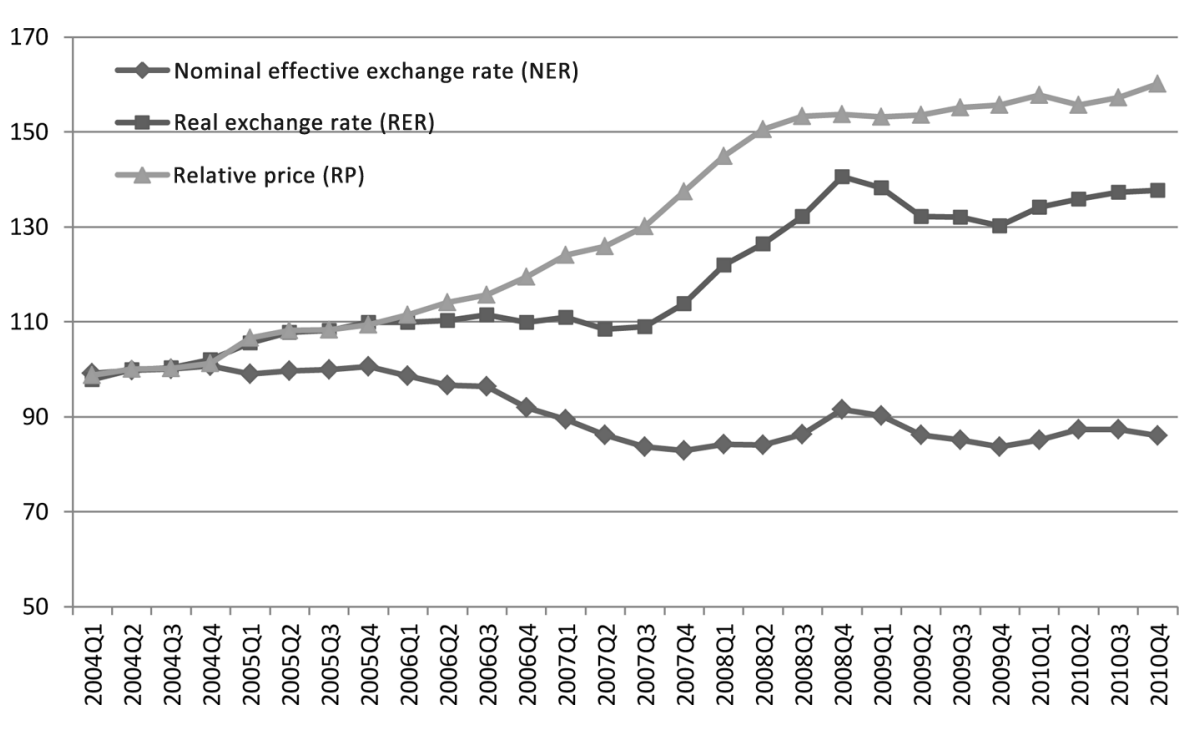

Source: Compiled from Central bank of Sri Lanka, Annual Report (various issues).

Note: NER = trade weighted nominal exchange rates relating to 24 top trading-partner countries (measured as foreign currency units per rupee); $R P=$ trade weights relative price (measured by the consumer price index) between Sri Lanka and its 24 top trading partners; $R E R=N E R^{*} R P ;$ an increase indicates appreciation.

The results were predictable. Before long the real exchange rate appreciated placing net exports under pressure, raising concerns about the widening of the current account. The stated objective of the government's macroeconomic policy was to achieve a "stable exchange rate regime" through appropriate coordination of exchange rate policy, and fiscal and monetary policies (Government of Sri Lanka 2010). But, in reality, while the Central Bank managed to maintain a stable nominal exchange rate based on the balance of payments support provided under the SBA, and foreign borrowing based on the market confidence provided by the SBA, ${ }^{27}$ fiscal and monetary policy excesses continued to fuel domestic inflation (Figure 3).

The immediate government response was in line with its nationalist-populist policy thrust. The government began to resort to administrative import controls in a systematic way to address the emerging payments deficit, accelerating the trend that had been noticeable since the election of President Rajapakse in 2005. This backsliding in trade policy is not an accident. In fact it is quite consistent with the

27 There was also some flow of foreign funds to the treasury bill market following the opening of that market to foreign investors (with an aggregate ceiling of 10 percent of the outstanding treasury bill issues) (CBSL 2010). 


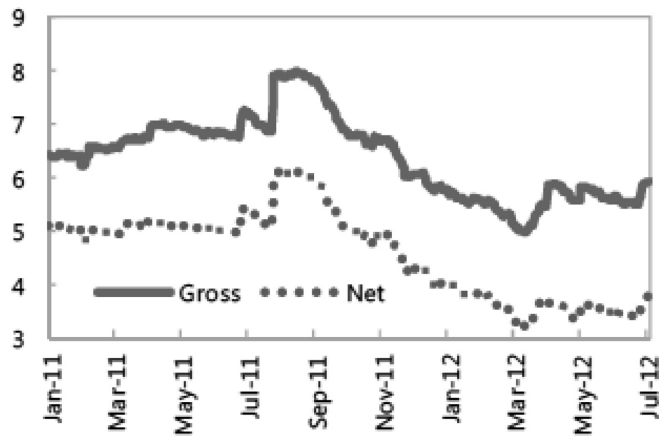

Source: IMF (2012).

nationalist-populist rhetoric of the government and the ideology espoused by its principal policy advisors. Not accidentally, these policies also favored the interests of business groups in import-competing industries, who have given strong political support to the government.

A real exchange appreciation in a period of global economic slowdown was certainly not good news for Sri Lanka's net exports. In the face of a persistent erosion of the competitiveness of tradable industries, limited trade restrictions were not sufficiently effective to address the widening current account deficit even in the short term. Sri Lanka's exports to GDP ratio fell from 26 percent in 2005 to 17.8 percent in 2011. The current account deficit widened to 2.2 percent of GDP in 2010 and to 7.8 percent of GDP in 2011; its financing required increasing reliance on foreign nonconcessional and commercial borrowings. As a result, the share of non-concessional loans and commercial borrowing in Sri Lanka's outstanding foreign debt increased sharply from 7.3 percent in 2006 to 42.9 percent in 2011 and its net international reserves rapidly fell to a precarious level. The Central Bank policy of attempting to maintain the clearly over-valued currency resulted only in the depletion of much of the foreign reserves as it was finally forced to abandon its attempt to maintain a "strong Rupee" in February 2012. The Rupee rapidly depreciated by some 25 percent against the U.S. dollar by August 2012. Whether this nominal exchange rate adjustment will bring about necessary current account adjustment through real exchange depreciation, or whether the country will sink into a debt trap and an eventual financial crisis, will depend on the government's readiness and ability to engineer necessary adjustments on the domestic fiscal front.

But this would not be an easy task. The budget deficit as a percentage of GDP increased from 7.7 percent in 2008 to 9.9 percent in 2010, far above the 7 percent target 
for the year under the SBA. Achieving the SBA target necessitated cutting public spending, but the government failed to resist strong domestic pressure to increase expenditure on civil service and armed forces, which constitute important political lobby groups. Loss-making public enterprises also continued to remain a huge drain on the fiscal position. Notwithstanding the ballooning budget deficit, the central government's debt as a percentage of GDP remained within apparently manageable levels (around 86 percent), but this was a rather deceptive indicator of fiscal health of the country: a shift in government borrowing from relatively high-cost domestic to lower-cost foreign sources combined with the "stable Rupee policy" resulted in reduction of the external debt stock in current rupee terms. ${ }^{28}$ Funds generated through the sovereign bond issues were also used to retire part of the high-interest domestic debt.

Thus three years after the end of the war, Sri Lanka faces a volatile global economic environment with a weakened economy, policy instability, low reserves, and a historically unprecedented level of commercial debt. Its attempt to pursue a path of nationalist populist economic policies has led the country into a situation different to what was anticipated by the government and its policy advisers.

\section{Prospects and challenges}

After showing remarkable resilience during decades of war and conflict the Sri Lankan economy has failed to capitalize on the window of opportunity presented by the end of the military conflict. Sri Lanka's tale of missed opportunities continues. We have provided a brief narrative of the outcome of the government's attempt to follow the military victory with an economic strategy rooted in the nationalistpopulist ideology of the 1960s and 1970s. It has, as was predictable and inevitable, ended in failure. Policies based on the past paradigm of inward- oriented, statecentered and -directed economic development do not offer a viable long-term solution to the huge challenges facing Sri Lanka, a small, capital- and resource-poor country. These policies, as we described earlier, failed not only in terms of economic growth but also contributed to the political alienation of minorities leading to violent ethnic conflicts by allowing political patronage to influence access to employment and public infrastructure.

It would be a tragedy if Sri Lanka were to forget the bitter lessons of the past. It has already paid a heavy price for past missed opportunities. It is no longer the

28 The Central Bank raised US\$ 2000 million through sovereign bond issues during 2007-10 at an interest rates of 6.25-6.5 percent (with is almost half of the rate applicable to domestic borrowing) (CBSL 2010). In addition there was massive borrowing from China, mostly at concessional rates, to fund infrastructure projects. 
pioneering, liberalizing country of the late 1970s. It is now forced to compete for foreign investment and export markets with the giant labor-rich economies of China and India as well as with countries such as Vietnam and Bangladesh. Further, it faces a global economy that is in deeper trouble than at any time since the 1930s. Sri Lanka can benefit from continuing growth in the Asian region, but only if can articulate and implement a development strategy that enables it to leverage its comparative advantages, attract investments, and participate in international production networks to generate productive mass employment. That requires fundamental reforms to policy and governance structures.

But such changes will encounter resistance from powerful political economy forces. Political power, including control over the security forces, has been concentrated to an unprecedented degree in a small group around the President and his immediate family; this is also the case with state finances, where control over the majority of government spending is directly in the hands of the President and his close family group. Macroeconomic pressures can, and, to some extent, already have produced some shifts in economic policy as the political elite manoeuvres to maintain economic stability without letting go of their political power and control over state resources that are the basis for rent extraction and political patronage. But, particularly in the current environment of global economic instability and shocks, sustainable long-term growth requires a political regime whose commitment to fundamental economic and political reforms will be credible and sustained. With the situation in Sri Lanka increasingly exhibiting striking parallels with the Marcos regime in the Philippines and the final phase of the Suharto regime in Indonesia, the likelihood of a fundamental change in economic policy and governance under the present regime appears slim indeed.

The policy reforms initiated in 1977 and sustained over the next three decades produced far-reaching changes in the structure and performance of the Sri Lankan economy, though the country suffered from political turbulence and civil war for much of the period. But the conflicts prevented the economy from capturing the full benefits of reintegrating with the global economy: political instability led to policy instability, massive war financing generated macroeconomic instability, and heightened risk perceptions dampened investor confidence. Nevertheless, trade liberalization enabled the country to capitalize on its comparative advantage in laborintensive activities. Despite political conflicts and policy uncertainty, this policy configuration ensured handsome profits in labor-intensive export production, which is usually characterized by a short payback period in a labor-abundant economy, and fostered rapid export growth. What the Sri Lankan experience over the past three decades has clearly demonstrated is that an outward-oriented policy regime, even 
when severely strained by political and macroeconomic instability, can yield a superior development outcome compared to a closed-economy regime. Viewed from this perspective, recent developments in the policy scene do not augur well for the future of the Sri Lankan economy.

In highlighting the importance of economic policies, we do not intend to underestimate the need for a political process that addresses the legitimate and deep-seated grievances of the minority Tamil population to ensure a sustainable peace that is essential for economic development. The continued incarceration of thousands, the denial of long-standing demands for regional autonomy and the withdrawal of concessions that had been previously granted, the rejection of any serious attempt to examine allegations of war crimes, and the strident assertion of the Sinhala Buddhist pre-eminence in Sri Lanka have all contributed to a deepening sense among the minority Tamils that they will continue to be treated as second-class citizens despite the rhetoric of reconciliation and equality of treatment. There are already signs of popular dissatisfaction with the rising cost of living, perceived widening of inequalities, and the economic and political privileges of the political elite. ${ }^{29}$ As Sri Lanka's past history has shown, political stability and social peace will be the first victims of economic stagnation or crisis; they can be averted only if the current direction of both political practice and economic policy are changed sharply, decisively and urgently.

\section{References}

Abeyratne, Sirimal. 2004. Economic Roots of Political Conflict: The Case of Sri Lanka. World Economy 27(8):1295-1314.

Adam, Christopher S., and David L. Bevan. 2006. Aid and the Supply Side: Public Investment, Export Performance, and Dutch Disease in Low-Income Countries. World Bank Economic Review 20(2):261-290.

Arunatilake, Nisha, Sisira Jayasuriya, and Saman Kelegama. 2001. The Economic Cost of the War in Sri Lanka. World Development 29(9):1483-1500.

Athukorala, Prema-chandra. 2004. Growth of Manufactured Export and Terms of Trade: Pessimism Confounded. In Economic Policy in Sri Lanka: Issues and Debates, edited by Saman Kelegama, pp. 37-53. New Delhi: Sage.

29 In 2012 there were several instances of popular protest actions, including mass demonstrations by thousands of workers in the export processing zones against an alleged police killing of a young worker that quickly took on anti-government overtones and a prolonged and unprecedented strike by university academics, which prompted the government to close all universities. 
Athukorala, Prema-chandra, and Sisira Jayasuriya. 1994. Macroeconomic Policies, Crises and Growth in Sri Lanka, 1969-1990. Washington, DC: World Bank.

Athukorala, Prema-chandra, and Sarath Rajapatirana. 2000. Liberalization and Industrial Transformation: Sri Lanka in International Perspective. Economic Development and Cultural Change 48(5):543-572.

Bandara, Jayatilake, and Sisira Jayasuriya. 2009. Sri Lanka. In Distortions to Agricultural Incentives in Asia, edited by K. Anderson and W. Martin, pp. 409-440. Washington, DC: World Bank.

Bruton, Henry. 1992. Sri Lanka and Malaysia: The Political Economy of Poverty, Equity, and Growth. New York: Oxford University Press.

CBSL (Central Bank of Sri Lanka). 2010. Public Debt Management in Sri Lanka: Performance in 2010 and Strategies for 2011 and Beyond. Colombo: CBSL.

Collier, Paul. 1999. On Economic Consequences of Civil War. Oxford Economic Papers 51(1):168183.

Collier, Paul, and Anke Hoeffler. 2004. Greed and Grievance in Civil War. Oxford Economic Papers 56(4):563-595.

Coyne, Christopher, G. Dempster, and J. Isaacs. 2010. Asset Values and the Sustainability of Peace Prospects. Quarterly Review of Economics and Finance 5092: 146-56.

Coyne, Christopher J., and Rachel L. Mathers. 2011. The Handbook on the Political Economy of War. Cheltenham, UK: Edward Elgar.

Cuthbertson, Andrew G. 1997. The Trade Policy Review of Sri Lanka. World Economy 20(5):633648.

de Silva, K. M. 1981. A History of Ceylon Delhi: Oxford University Press.

Dunham, David, and Sisira Jayasuriya. 2000. Equity, Growth and Insurrection: Liberalization and the Welfare Debate in Contemporary Sri Lanka. Oxford Development Studies 28(1):97-110.

Dunham, David, and Saman Kelegama. 1997. Does Leadership Matters in the Economic Reform Process? Liberalization and Governance in Sri Lanka. World Development 25(2):179-190.

Easterly, William, and Ross Levine. 1997. Africa's Growth Tragedy: Policies and Ethnic Division. Quarterly Journal of Economics 112(4):1203-1250.

Ekanayake, A. Raveen. 2011. Global Economic Integration via Foreign Direct Investment: Opportunities and Policy Options for Sri Lanka. Masters Research Essay. Australian National University, Canberra: Crawford School of Economics and Government.

Goodhand, J. 2012. Sri Lanka in 2011: Consolidation and Militarization of the Post-War Regime. Asian Survey 52(1):130-137.

Government of Sri Lanka. 2006. Mahinda Chinatana: Vision for A New Sri Lanka, Colombo: Department of National Planning.

Government of Sri Lanka. 2008. Strategic Development Projects Act, No. 14 of 2008. Sri Lanka: Government Publication Bureau.

Government of Sri Lanka. 2010. Sri Lanka: The Emerging Wonder of Asia: Mahinda Chintana Vision for the Future Colombo: Department of National Planning. 
Government of Sri Lanka. 2011. Budget Speech 2011. Colombo: Ministry of Finance and Planning.

Hettige, Siri. 2004. Economic Policies, Changing Opportunities for Youth and the Ethnic Conflict in Sri Lanka. In Economy, Culture and Civil War in Sri Lanka, edited by Deborah Winslow and Michael D. Woost, pp. 115-132. Bloomington: University of Indiana Press.

IMF (International Monetary Fund). 2012. Sri Lanka: Eighth Review under the Stand-By Agreement. Washington, DC: IMF.

IPS (Institute of Policy Studies). 2012. Sri Lanka: State of the Economy 2010. Colombo: IPS.

Kravis, Irwin B., Allen Heston, and Robert Summers. 1983. World Production and Income: International Comparison of Real Gross Product. Baltimore, MD: Johns Hopkins University Press.

Moore, Mick. 1993. Thoroughly Modern Revolutionaries: The JVP in Sri Lanka. Modern Asian Studies 27(3):593-642.

Moore, Mick. 1997. Leading the Left to the Right: Populist Coalitions and Economic Reforms. World Development 25(7):1009-1028.

Obeyesekere, Gananath. 1974. Some Comments on the Social background of the April 1971 Insurgency in Sri Lanka. Journal of Asian Studies 33(3):367-384.

Osmani, S. R. 1994. Is there a conflict between growth and welfarism? The significance of the Sri Lanka debate. Development and Change 25:387-421.

Panagariya, Arvind. 2002. Trade Liberalization in Asia. In Going Alone: The Case for Relaxed Reciprocity in Freeing Trade, edited by J. Bhagwati, pp. 219-302. Cambridge, MA: MIT Press.

Pursell, Garry. 2011a. Para Tariffs and Sri Lanka's New Protectionism. Economic and Political Weekly 76(25):31-34.

Pursell, Garry. 2011b. Trade Policies in South Asia. In Routledge Handbook of South Asian Economies, edited by Raghavendra Jha, pp. 219-237. London: Routledge.

Pursell, Garry, and F. M. Z. Ahsan. 2011. Sri Lanka's Trade Policies: Back to Protectionism. Australia South Asia Research Centre Working Paper 2011/03. Canberra: Australian National University.

Rajapatirana, Sarath. 1989. Foreign Trade and Economic Development: Sri Lanka's Experience. World Development 16:1143-1157.

Rajapatirana, Sarath. 2004. Industry Policy. In Economic Policy in Sri Lanka: Issues and Debates, edited by Saman Kelegama, pp. 213-236. New Delhi: Sage.

Richardson, John. 2005. Paradise Poisoned: Learning about Conflict, Terrorism and Development of Sri Lanka's Civil Wars. Kandy, Sri Lanka: International Centre for Ethnic Studies.

Snodgrass, Donald R. 1998. The Economic Development of Sri Lanka: A Tale of Missed Opportunities. In Creating Peace in Sri Lanka: Civil War and Reconciliation, edited by Robert I. Rotberg, pp. 89-107. Washington, DC: Brookings Institution Press.

Wilson, A. Jayatatnam. 1988. The Break-up of Sri Lanka: The Sinhalese-Tamil Conflict. Honolulu: University of Hawaii Press.

World Bank. 2004. Sri Lanka Development Policy Review (Report No. 29396-LK). Washington, DC: World Bank. 
World Bank. 2010. Investing Across Borders 2010: Indicators of Foreign Direct Investment Indicators in 87 Countries. Washington, DC: World Bank.

World Bank. 2011. World Development Report 2011. Washington, DC: World Bank.

Wriggins, W. Howard. 1960. Ceylon: Dilemmas of a New Nation. Princeton, NJ: Princeton University Press. 